\title{
PENERAPAN MODEL PROBLEM BASED LEARNING UNTUK MENUMBUHKEMBANGKAN HIGHER ORDER THINKING SKILL SISWA SEKOLAH DASAR
}

\author{
Cholifah Tur Rosidah \\ Pendidikan Guru Sekolah Dasar Universitas PGRI Adi Buana Surabaya \\ cholifah@unipasby.ac.id
}

\begin{abstract}
Abstrak
Mengkaji penerapan model Problem Based Learning (PBL) untuk menumbuhkembangkan Higher Order Thinking Skill (HOTS) siswa Sekolah Dasar. Artikel ini ditulis melalui studi kepustakaan. PBL merupakan model dengan pendekatan belajar pada masalah autentik, sehingga siswa mampu menyusun pengetahuannya sendiri. PBL bercirikan menggunakan masalah yang riil sebagai bahan belajar siswa untuk melatih dan menumbuhkembangkan keterampilan berrpikir kritis serta pemecahan masalah guna mendapatkan konsep-konsep pengetahuan. HOTS adalah salah satu komponen yang harus dikembangkan dalam setiap pelaksanaan proses pembelajaran Kurikulum 2013. Aktivitas belajar harus dirancang agar siswa memiliki keterampilan berpikir tingkat tinggi. Berdasarkan hasil kajian, sintaks pembelajaran model PBL yang terlihat pada aktivitas belajar siswa dapat melatih dan menumbuhkembangkan high order thingking skill siswa, karena siswa memperoleh pengalaman secara langsung dan dapat mengubah tingkah laku (pengetahuan, ketrampilan, sikap) baik segi kuantitas maupun kualitas. Kata Kunci : Model Pembelajaran, Problem Based Learning, Higher Order Thinking Skill
\end{abstract}

\section{IMPLEMENTATION OF PROBLEM BASED LEARNING (PBL) MODEL TO DEVELOP HIGHER ORDER THINKING SKILL (HOTS) IN ELEMENTARY SCHOOL'S STUDENT}

\begin{abstract}
Study about implementation of Problem Based Learning (PBL) model to develop Higher Order Thinking Skill (HOTS) in elementary school's student. This article was written through study literature. Problem Based Learning is a model with teaching approach at authentic issue, so the students are able to compose their knowledge own. Characterized of Problem Based Learning is using the real life problem as something to be learned students to train and improved the skills of think critically and problem solving in order to obtain concepts knowledge. HOTS or the capacity to think a high degree is one of components must be maintained in any process learning did as teachers on the application of 2013 Curriculum. Learning activities must be designed that students have skills think high level. Through a
\end{abstract}


Problem Based Learning model, higher order thinking skill of students will be trained and developing, and they can gain experience directly and change mannerisms (knowledge, skills, attitude) both in terms of quality and quantity.

Keywords: Learning Model, Problem Based Learning, Higher Order Thinking Skill

\section{A. PENDAhUluAN}

Kurikulum 2013 merupakan kurikulum yang menganut pandangan dasar bahwa pengetahuan yang harus dikuasai siswa tidak dapat ditransfer atau dituangkan langsung oleh guru ke siswa. Namun, siswa adalah subjek pendidikan yang memiliki potensi aktif untuk dapat mencari, menemukan, mengkonstruksi, mengolah, dan menggunakan pengetahuannya. Penerapan kegiatan pembelajaran Kurikulum 2013 diarahkan untuk memberdayakan seluruh potensi siswa agar mereka memiliki kompetensi unggul, baik dalam sikap, pengetahuan maupun keterampilan sesuai tujuan pembelajaran yang ingin dicapai. Kualitas lain yang hendak direalisasikan dalam pembelajaran Kurikulum 2013 adalah tumbuhkembang kemandirian, kreativitas, solidaritas, kerjasama, kepemimpinan, toleransi, empati, dan kecakapan hidup siswa guna memupuk karakter yang dapat meningkatkan peradaban dan harkat martabat bangsa.

Prinsip-prinsip yang harus diperhatikan dalam proses pelaksanaan kegiatan pembelajaran Kurikulum 2013 menurut Hosnan (2014) diantaranya (1) proses pembelajaran hendaknya berpusat pada siswa atau student center, (2) selalu mengedepankan pengembangan kreativitas siswa, (3) mengondisikan dan memanipulasi proses pembelajaran yang menantang dan menyenangkan, (4) menanamkan nilai, etika, logika, estetika, dan kinestetika, serta (5) menyiapkan pengalaman belajar yang bervariasi melalui penerapan berbagai strategi, model, dan metode pembelajaran yang menyenangkan, kontekstual, efektif, efisien, dan bermakna. Berdasarkan prinsip-prinsip tersebut, siswa dibimbing untuk menemukan dan mentransformasi pengetahuan yang kompleks, mengasosiasi informasi baru dengan informasi yang dimiliki sebelumnya, serta melakukan pengembangan menjadi informasi atau kemampuan yang sesuai dengan lingkungan tempat mereka tinggal. Selain itu agar siswa benar-benar memahami dan mampu menerapkan pengetahuannya, siswa juga perlu dibimbing untuk dapat menyelesaikan masalah, menemukan solusi untuk dirinya, dan berusaha untuk mewujudkan ide-idenya. Oleh karena itu pembelajaran harus memberikan kesempatan kepada siswa untuk mengonstruksi pengetahuan dalam proses kognitifnya.

Model - model pembelajaran yang diterapkan dalam kurikulum 2013 diantaranya pembelajaran berbasis masalah, pembelajaran berbasis proyek, dan pembelajran penemuan. Model pembelajaran berbasis masalah merupakan model pembelajaran yang bercirikan pada pembahasan materi dengan menggunakan maslah autentik. Model tersebut lebih menarik, menantang, dan membiasakan siswa untuk menghadapai masalah-masalah yang terjadi serta mencari solusi terbaik untuk sebuah permasalahan. Pencarian solusi tersebut tentunya membutuhkan kemampuan berpikir kritis siswa. 
Namun realita disekolah tidak sedikit yang membuktikan bahwa kemampuan berpikir kritis siswa masih tergolong rendah. Hal itu ditunjukkan ketika mereka dihadapkan dengan permasalahan-permasalahan yang menuntut mereka untuk menganalisis, mengevaluasi, dan memunculkan ide barunya untuk menemukan solusi atas permasalahan yang dihadapi.

Penelitian terdahulu terkait model PBL dilaksanakan oleh Setyorini (2011), yang melaksanakan model pembelajaran PBL pada siswa SMP pada materi gerak lurus berubah beraturan menyimpulkan bahwa model PBL dapat meningkatkan kemampuan berpikir kritis siswa. Penelitian lain tentang penerapan model PBL juga dilakukan oleh Arnyana (2007) dengan subyek penelitian siswa SMA menyimpulkan bahwa model PBL dapat meningkatkan pemahaman konsep, kemampuan memecahkan masalah, kemampuan menerapkan konsep-konsep, sikap positif siswa, dan kemampuan berpikir kritis siswa.

Berdasarkan beberapa hasil penelitian terdahulu tersebut, menjadi hal yang menantang untuk melakukan kajian tentang penerapan model Problem Based Learning untuk menumbuhkembangkan Higher Order Thinking Skill siswa Sekolah Dasar.

\section{B. TINJAUAN PUSTAKA}

\section{Model Problem Based Learning (PBL)}

Barrows dalam Hosnan (2014) menyatakan pembelajaran berbasis masalah (Problem Based Learning) bermula dikembangkan sebagai respon atas fakta yang menunjukkan banyak dokter muda yang baru lulus dari sekolah kedokteran di Ontorio, Kanada pada tahun 1960an memiliki pengetahuan yang sangat kaya dan luas. Namun, kebanyakan dari mereka kurang memiliki keterampilan untuk dapat memanfaatkan pengetahuannya tersebut dalam praktik di masyarakat. Untuk itu dikembangkanlah pembelajaran berbasis masalah. Kini perkembangan selanjutnya, PBL secara lebih luas diterapkan dalam berbagai bidang ilmu di sekolah maupun perguruan tinggi.

\section{a. Hakikat Model Problem Based Learning (PBL)}

Model Pembelajaran PBL ialah pembelajaran yang menerapkan pendekatan pemberian masalah autentik pada siswa (Arends dalam Abbas: 2010). Dengan pemberian masalah tersebut, siswa dapat mengumpulkan fakta, mengkonstruksi pengetahuan, menumbuhkembangkan keterampilan berpikir, melatih kemandirian, dan meningkatkan kepercayaan diri. Selanjutnya Ibrahim dalam Hosnan (2014) berpendapat bahwa PBL merupakan pembelajaran yang menekankan pada pengembangan keterampilan berpikir dan penyelesaian masalah. Dari beberapa pendapat yang telah dipaparkan disimpulkan PBL adalah model pembelajaran yang berorientasi pada masalah autentik, agar dapat mengeksplorasi keterampilan 
berpikir siswa, sehingga mereka mampu membangun pengetahuannya sendiri dan menyelesaikan berbagai masalah yang dihadapi.

Implementasi model PBL tidak hanya berorientasi pada pemerolehan pengetahuan deklaratif, namun juga pemerolehan pengetahuan prosedural. Sebagian permasalahan yang ada bersifat dinamis sesuai dengan kemajuan teknologi dan perkembangan jaman. Maka pemberian masalah yang diaplikasikan dalam pembelajaran dengan menerapkan model PBL hendaknya sesuai dengan konteks atau masalah yang terjadi saat ini, sehingga memungkinkan siswa mengetahui cara belajarnya (how to learn) dan aktif mengembangkan kerangka berpikir dalam pemecahan masalah.

Adapun pertanyaan dan masalah yang diangkat dalam pembelajaran harus memenuhi kriteria berikut (Arend dalam Hosnan: 2014).

1) Autentik, masalah harus bersumber dan berakar pada keidupan nyata siswa dari pada berakar pada prinsip-prinsip disiplin ilmu tertentu.

2) Jelas, masalah harus dirumuskan dengan jelas sehingga tidak menimbulkan persepsi ganda yang dapat menimbulkan permasalahan baru bagi siswa dan menyulitkan untuk diselesaikan.

3) Mudah dipahami, masalah hendaknya sesuai dengan tingkat perkembangan siswa, sehingga mampu dipahami dengan mudah olehnya.

4) Luas dan sesuai tujuan pembelajaran, masalah harus mencakup seluruh muatan pelajaran yang disampaikan pada dimensi ruang, waktu dan media tertentu sesuai tujuan pembelajaran.

5) Bermanfaat, masalah hendaknya bermanfaat bagi siswa, sehingga dapat

menumbuhkembangkan keterampilan berpikir, memecahkan masalah, dan memotivasi siswa belajar.

\section{b. Tujuan Model Problem Based Learning (PBL)}

Tujuan utama PBL ialah untuk mengembangkan keterampilan berpikir kritis dan memecahkan masalah serta kemampuan untuk membangun pengetahunnya sendiri. PBL tidak dimaksudkan untuk menyampaikan sejumlah besar pengetahuan, namun untuk mengembangkan kemandirian belajar melalui kolaborasi saat mengidentifikasi informasi, strategi, dan sumber-sumber 
yang relevan dalam penyelesaian masalah.

\section{c. Sintaks Model Problem Based Learning (PBL)}

Implementasi model PBL terdiri atas lima langkah utama, antara lain:

1) Orientasi siswa pada masalah, pada tahap ini guru memberikan penjelasan terkait tujuan pembelajaran, kebutuhan atau logistik yang diperlukan, serta memberikan motivasi pada siswa agar berpartisipasi aktif dalam setiap tahapan aktivitas pemecahan masalah.

2) Mengorganisasi siswa dalam belajar, pada tahap ini guru mengorganisasikan siswa melalui pemberian bantuan dalam membuat definisi dan organisasi tugas belajar terkait penyelesaian masalah.

3) Bimbingan penyelidikan individu maupun kelompok, pada tahap ini guru memotivasi dan membimbing siswa dalam pengumpulan data-data yang sesuai. Selain itu guru juga membimbing siswa dalam melaksanakan eksperimen guna memperoleh penjelasan untuk pemecahan masalah.

4) Pengembangan dan penyajian hasil karya, pada tahap ini guru membimbing siswa dalam membuat perencanaan dan persiapan penyajian hasil karya sesuai laporan penyelesaian masalah seperti prototipe, video, gambar, dokumen presentasi, dan lainnya.

5) Analisis dan evaluasi proses pemecahan masalah, pada tahap ini guru membimbing siswa dalam proses refleksi dan evaluasi terhadap proses-proses penyelidikan dalam penyelesaian masalah yang telah dilaksanakan.

\section{Perkembangan Kemampuan Berpikir Anak SD}

Perkembangan kemampuan berpikir atau perkembangan kognitif meliputi aspek struktur intelek yang dimanfaatkan untuk mengolah informasi melalui stimuli yang mereka dapatkan hingga memberikan respon secara tepat (Danim: 2013). Aspek yang termasuk perkembangan kognitif diantaranya meliputi persepsi, ingatan, pikiran, simbol, penalaran, dan pemecahan masalah.

Perkembangan kognitif siswa SD berada pada tahapan operasional konkrit yaitu mereka yang berusia 7 sampai 11 tahun. Selain itu juga ada yang berada pada tahap operasional formal bagi mereka yang berusia 11 sampai 12 tahun. Pada tahap operasional konkrit siswa telah mampu melaksanakan berbagai tugas dan mengkonservasi angka. Beberapa proses operasi yang dapat dilakukan siswa pada tahap tersebut adalah 1) negasi sebagai bentuk kemampuan siswa dalam 
memahami proses antar kegiatan dan hubungan antara keduanya; 2) resiprokasi sebagai kemampuan untuk melihat hubungan timbal balik; 3) identitas dalam mengenali benda-benda yang ada. Dari proses operasi tersebut dapat dipahami bahwa siswa SD telah mampu berpikir konkrit dalam memahami sesuatu seperti pada realita yang dialami atau disaksikannya.

\section{Higher Order Thinking Skill (HOTS)}

Higher Order Tinking Skill adalah kemampuan berpikir kritis, logis, reflektif, metakognitif, dan berpikir kreatif. Berpikir kritis merupakan suatu proses intelektual dalam pemahaman konsep, pengaplikasian, analisis, sintesis dan atau pengevaluasian berbagai informasi yang didapat dari hasil observasi, pengalaman, dan refleksi sebagai dasar pengambilan tindakan (Walker: 2006). Pendapat tersebut didukung dengan pendapat Hassoubah (2007), yang menyatakan bahwa berpikir kritis merupakan kemampuan memberi alasan secara terorganisir dan sistematis. Sehingga dapat didefinisikan berpikir kritis adalah proses intelektual dalam memahami, megaplikasikan, menganalisis, mensistesis, dan mengevaluasi suatu informasi secara terorganisis dan sistematis.

Berpikir logis juga merupakan salah satu indikator dari HOTS. Berpikir logis ialah suatu proses berpikir dengan menggunakan logika, rasional, dan masuk akal. Dengan berpikir logis, kita dapat membedakan dan mengkritisi kejadian-kejadian yang terjadi apakah fenomena tersebut masuk akal dan sesuai dengan ilmu pengetahuan.

$$
\text { Selanjutnya yang }
$$

merupakan indikator dari HOTS adalah berpikir reflektif (Reflective Thinking). John Dewey mengemukakan pemikirannya tentang berpikir reflektif yakni suatu proses berpikir aktif hatihati, yang dilandasi proses berpikir kea rah kesimpulan-kesimpulan yang definitive melalui lima langkah sebagai berikut, 1) peserta didik harus mengenali masalah, 2) peserta didik hendaknya menyelidiki dan menganalisa kesulitan dan menentukan masalah yang dihadapi, 3) peserta didik mengaitkan uraian-uraian hasil analisis dan mengumpulkan berbagai kemungkinan guna menemukan solusi dan langkah untuk bertindak, 4) mengevaluasi kemungkinan solusi atau hipotesis dengan akibatnya masing-masing, 5) selanjutnya peserta didik mempraktekkan salah satu kemungkinan pemecahan yang dinilai terbaik. Hasilnya akan membuktikan betul-tidaknya pemecahan masalah tersebut, hingga di dapatkan pemecahan masalah yang tepat. Indikator HOTS yang berikutnya adalah metakognisi, yakni pengetahuan tentang objek-objek kognitif. Penekanan metakognisi ada pada kesadaran berpikir seseorang tentang proses berpikirnya. Indikator terakhir dari HOTS adalah berpikir kritis yakni kemampuan berpikir untuk 
mencapai produk yang beragam dan baru.

Nampak dari beberapa indikatornya, HOTS merupakan kemampuan berpikir level 3. Jika digambarkan dalam taksonomi bloom pada ranah kognitif, HOTS berada pada tingkat C4 sampai C6 seperti pada gambar 1 berikut ini.

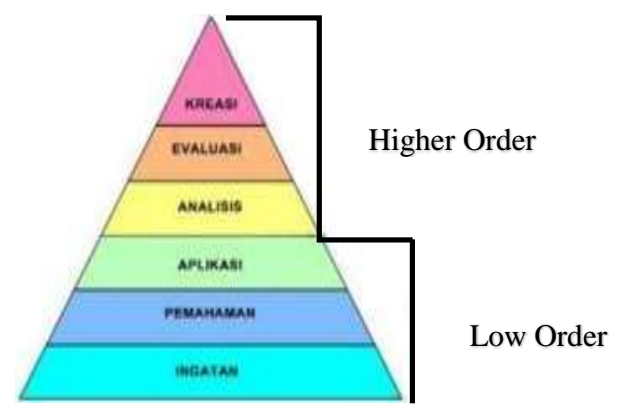

Gambar 1. ranah kognitif taksonomi bloom

C. PEMBAHASAN

Penerapan Model Problem Based Learning (PBL) untuk menumbuhkembangkan Higher Order Thinking Skill (HOTS) Siswa Sekolah Dasar

\section{Contoh Rancangan Penerapan} Model Problem Based Learning (PBL) pada Materi Kebebasan Berorganisasi pada Siswa Kelas V Sekolah Dasar

Topik materi kebebasan berorganisasi dilaksanakan di kelas V semester 2. Adapun rancangan yang dapat dilakukan guru untuk membelajarkan materi tersebut sesuai sisntaks pembelajaran model PBL adalah sebagai berikut.

\begin{tabular}{|c|c|c|}
\hline No. & Fase & Aktivitas \\
\hline \multicolumn{3}{|c|}{ Tahap 1 (Orientasi siswa pada masalah) } \\
\hline 1 & $\begin{array}{l}\text { Menyiapkan } \\
\text { sarana atau } \\
\text { logistik berupa } \\
\text { software maupun } \\
\text { hardware yang } \\
\text { dibutuhkan dalam } \\
\text { bentuk masalah } \\
\text { yang dapat } \\
\text { mengundang } \\
\text { pertanyaan dan } \\
\text { belum } \\
\text { terdefinisikan } \\
\text { secara jelas }\end{array}$ & $\begin{array}{l}\text { a. Menyiapkan topik } \\
\text { yang akan dijadikan } \\
\text { masalah dalam } \\
\text { pembelajaran } \\
\text { dengan menganalisis } \\
\text { kemungkinan } \\
\text { materi/konsep yang } \\
\text { mau diajarkan } \\
\text { memungkinkan } \\
\text { dijadikan masalah. } \\
\text { Dalam pembahasan } \\
\text { ini terkait materi } \\
\text { kebebasan } \\
\text { berorganisasi } \\
\text { (Software). } \\
\text { b. Menyiapkan sarana } \\
\text { pendukung } \\
\text { (hardware) } \\
\text { Misalnya terkait } \\
\text { materi kebebasan } \\
\text { berorganisasi bisa } \\
\text { ditampilkan video } \\
\text { pembubaran salah } \\
\text { satu organisasi di } \\
\text { Indonesia }\end{array}$ \\
\hline 2 & $\begin{array}{l}\text { Mengajukan } \\
\text { fenomena, } \\
\text { demonstrasi, atau } \\
\text { cerita untuk } \\
\text { memunculkan } \\
\text { masalah. }\end{array}$ & $\begin{array}{l}\text { a. Mengajukan } \\
\text { fenomena, gejala- } \\
\text { gejala, demonstrasi, } \\
\text { atau cerita untuk } \\
\text { memunculkan dan } \\
\text { mempertajam dalam } \\
\text { masalah gam } \\
\text { bentuk gambar atau } \\
\text { film pendek. } \\
\text { Masalah yang baik } \\
\text { harus memenuhi } \\
\text { kriteria sebagai } \\
\text { berikut: } \\
\text { 1) Otentik, } \\
\text { masalah harus } \\
\text { berakar pada } \\
\text { dunia nyata } \\
\text { siswa. } \\
\text { Contoh: } \\
\text { pembubaran } \\
\text { salah satu } \\
\text { organisasi di } \\
\text { Indonesia. } \\
\text { Terdefinisikan } \\
\text { secara longgar, } \\
\text { masalah- } \\
\text { masalah yang }\end{array}$ \\
\hline
\end{tabular}




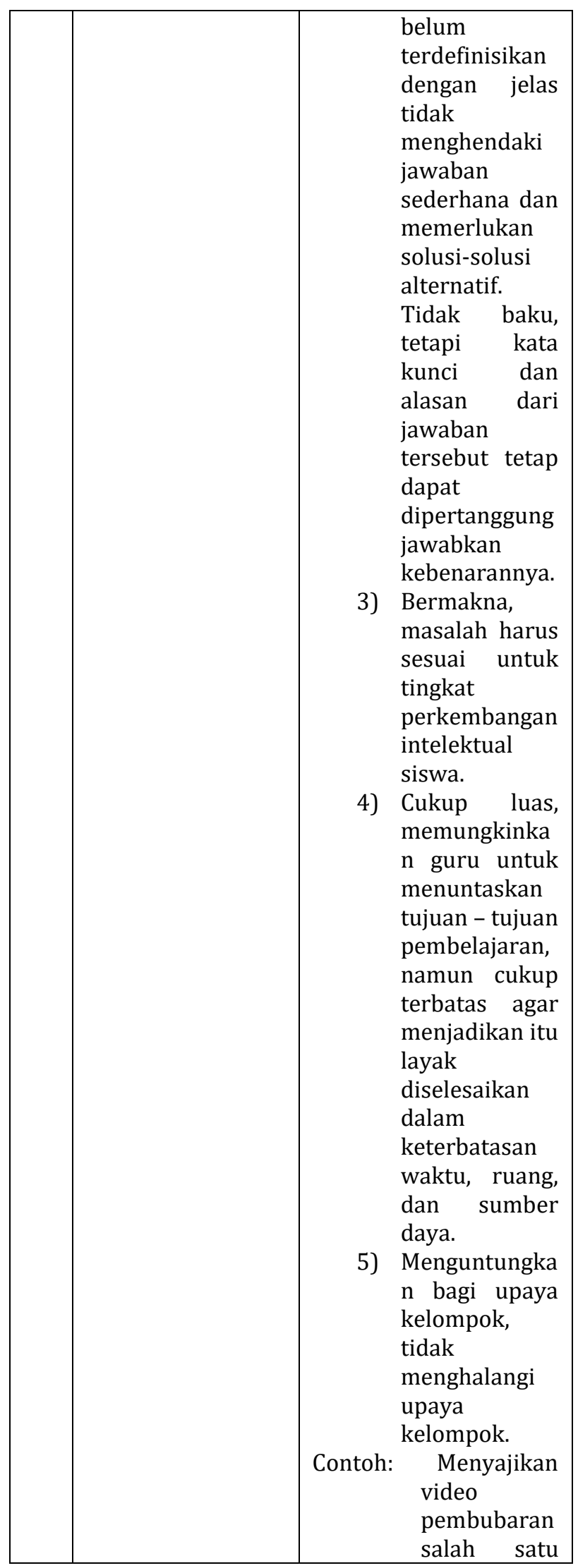

\begin{tabular}{|c|c|c|}
\hline & & $\begin{array}{l}\text { organisasi di } \\
\text { Indonesia }\end{array}$ \\
\hline 3 & $\begin{array}{l}\text { Mencermati } \\
\text { (mengamati) } \\
\text { sajian masalah }\end{array}$ & $\begin{array}{l}\text { a. Mengajukan } \\
\text { pertanyaan } \\
\text { pengarah agar } \\
\text { siswa mampu } \\
\text { memprediksi atau } \\
\text { mengajukan } \\
\text { hipotesis mengenai } \\
\text { pembubaran salah } \\
\text { satu organisasi di } \\
\text { Indonesia. } \\
\text { b. Memberikan } \\
\text { alternatif jawaban } \\
\text { masalah, jika siswa } \\
\text { tidak ada yang } \\
\text { mampu } \\
\text { memberikan } \\
\text { alternative jawaban. } \\
\text { c. Merumuskan } \\
\text { hipotesis atas } \\
\text { masalah yang } \\
\text { dipilih. }\end{array}$ \\
\hline 4 & $\begin{array}{l}\text { Menjelaskan } \\
\text { tujuan } \\
\text { pembelajaran }\end{array}$ & \begin{tabular}{lr}
\multicolumn{3}{l}{ Menjelaskan } & \\
kompetensi yang akan \\
dicapai & setelah \\
pembelajaran & usai \\
dilaksanakan. & \\
\end{tabular} \\
\hline 5 & $\begin{array}{l}\text { Memotivasi } \\
\text { peserta didik } \\
\text { untuk terlibat aktif } \\
\text { dalam aktivitas } \\
\text { pemecahan } \\
\text { masalah }\end{array}$ & $\begin{array}{l}\text { Memberikan motivasi } \\
\text { pada siswa agar } \\
\text { berperan aktif selama } \\
\text { proses pembelajaran } \\
\text { agar } \\
\text { memecahkan masalah } \\
\text { dengan baik. }\end{array}$ \\
\hline
\end{tabular}

Tahap 2 (Mengorganisasi peserta didik untuk belajar)

\begin{tabular}{|c|l|l|}
\hline 1 & Membentuk & $\begin{array}{l}\text { Membentuk kelompok } \\
\text { kang terdiri dari 3-4 } \\
\text { siswa }\end{array}$ \\
\cline { 3 - 3 } & & $\begin{array}{l}\text { Menentukan ketua dan } \\
\text { anggota kelompok agar } \\
\text { dapat bekerjasama } \\
\text { dengan baik }\end{array}$ \\
\cline { 3 - 3 } & $\begin{array}{l}\text { Membuat nama } \\
\text { kelompok }\end{array}$ \\
\cline { 3 - 4 } & $\begin{array}{l}\text { Membuat yel-yel } \\
\text { kelompok }\end{array}$ \\
\hline 2 & $\begin{array}{l}\text { Mendefinisikan } \\
\text { tugas belajar }\end{array}$ & $\begin{array}{l}\text { Menjelaskan tugas } \\
\text { yang harus } \\
\text { diselesaikan selama } \\
\text { proses pembelajaran }\end{array}$ \\
\hline
\end{tabular}




\begin{tabular}{|c|c|c|}
\hline & & $\begin{array}{l}\text { Mengorganisasikan } \\
\text { peserta didik untuk } \\
\text { belajar dalam bentuk } \\
\text { diskusi kelompok kecil }\end{array}$ \\
\hline \multirow[t]{2}{*}{3} & \multirow[t]{2}{*}{$\begin{array}{l}\text { Mengidentifikasi } \\
\text { masalah }\end{array}$} & $\begin{array}{l}\text { Melalui kegiatan tanya } \\
\text { jawab, siswa } \\
\text { diingatkan kembali } \\
\text { langkah-langkah atau } \\
\text { metode ilmiah dalam } \\
\text { penyelesaian masalah. } \\
\text { Dapat juga disajikan } \\
\text { dalam bentuk diagram } \\
\text { alir. }\end{array}$ \\
\hline & & \begin{tabular}{lr}
\multicolumn{2}{l}{ Menjelaskan lebih rinci } \\
\multicolumn{2}{l}{ alternatif-alternatif } \\
strategi & untuk \\
menyelesaikan & \\
masalah & yang \\
ditentukan, & yaitu \\
terkait & dengan \\
kebebasan & \\
berorganisasi. &
\end{tabular} \\
\hline \multirow[t]{2}{*}{4} & \multirow[t]{2}{*}{$\begin{array}{l}\text { Merancang } \\
\text { eksperimen untuk } \\
\text { menguji hipotesis } \\
\text { yang diajukan }\end{array}$} & $\begin{array}{l}\text { Masing-masing } \\
\text { kelompok } \\
\text { mempresentasikan } \\
\text { hipotesis dan } \\
\text { rancangan pemecahan } \\
\text { masalah yang ada. }\end{array}$ \\
\hline & & $\begin{array}{lcc}\text { Kelompok } & \text { lain dan } \\
\text { guru } & \text { memberikan } \\
\text { penilaian } & \text { dan saran } \\
\text { terhadap } & \text { presentasi } \\
\text { tersebut. } & \\
\end{array}$ \\
\hline \multicolumn{3}{|c|}{$\begin{array}{l}\text { Tahap } 3 \text { (Bimbingan Penyelidikan Ind } \\
\text { Maupun Kelompok) }\end{array}$} \\
\hline \multirow[t]{5}{*}{1} & \multirow[t]{5}{*}{$\begin{array}{l}\text { Mengumpulkan } \\
\text { informasi terkait } \\
\text { masalah }\end{array}$} & \begin{tabular}{lr}
\multicolumn{2}{l}{ Mengumpulkan bukti } \\
dengan & mencari \\
informasi & melalui \\
media cetak & maupun \\
elektronik. & \\
\end{tabular} \\
\hline & & $\begin{array}{l}\text { Memanfaatkan } \\
\text { berbagai sumber } \\
\text { belajar (buku, internet, } \\
\text { dll) }\end{array}$ \\
\hline & & $\begin{array}{l}\text { Guru siap menjadi } \\
\text { sumber } \quad \text { belajar } \\
\text { (menyiapkan berbagai } \\
\text { sumber belajar) }\end{array}$ \\
\hline & & $\begin{array}{l}\text { Mengambil foto bukti- } \\
\text { bukti kebebasan } \\
\text { berorganisasi. }\end{array}$ \\
\hline & & $\begin{array}{lr}\text { Mencari data hak dan } \\
\text { kewajiban } & \text { terkait }\end{array}$ \\
\hline
\end{tabular}

\begin{tabular}{|c|c|c|}
\hline & & $\begin{array}{l}\text { kebebasan } \\
\text { berorganisasi. }\end{array}$ \\
\hline & & $\begin{array}{l}\text { Mencari contoh } \\
\text { organisasi yang ada di } \\
\text { sekolah }\end{array}$ \\
\hline 2 & Menganalisis data & $\begin{array}{lr}\text { Dari data yang } \\
\text { diperoleh dianalisis } \\
\text { untuk mendapatkan } \\
\text { solusi, bagaimana hak } \\
\text { dan kewajiban yang } \\
\text { harus dilakukan } & \text { suatu } \\
\text { organisasi r untuk } & \text { mendapatkan } \\
\text { kebebasannya } & \text { dalam } \\
\text { berorganisasi. }\end{array}$ \\
\hline 3 & $\begin{array}{l}\text { Melaksanakan } \\
\text { eksperimen untuk } \\
\text { mendapatkan } \\
\text { kejelasan yang } \\
\text { diperlukan dalam } \\
\text { penyelesaian } \\
\text { masalah }\end{array}$ & $\begin{array}{l}\text { Solusi yang ditemukan } \\
\text { diuji cobakan untuk } \\
\text { mendapatkan } \\
\text { kebenaran. Dalam hal } \\
\text { ini siswa bisa membuat } \\
\text { organisasi di sekolah. }\end{array}$ \\
\hline & 4 (Pengembang & Jajian Hasil \\
\hline 1 & $\begin{array}{l}\text { Mempresentasikan } \\
\text { hasil karya }\end{array}$ & $\begin{array}{l}\text { Siswa menampilkan } \\
\text { solusi yang } \\
\text { ditawarkannya terkait } \\
\text { hak dan kewajiban } \\
\text { dalam melaksanakan } \\
\text { kebebasan } \\
\text { berorganisasi }\end{array}$ \\
\hline & $\begin{array}{c}5 \text { (Analisis } \\
\text { cahan Masalah) }\end{array}$ & $\begin{array}{lll}\text { an } & \text { Evaluasi Proses } \\
\end{array}$ \\
\hline 1 & $\begin{array}{l}\text { Mengevaluasi } \\
\text { proses pemecahan } \\
\text { masalah }\end{array}$ & $\begin{array}{l}\text { Guru dan kelompok } \\
\text { lain dapat memberikan } \\
\text { pendapatnya terkait } \\
\text { dengan solusi yang } \\
\text { telah dijelaskan oleh } \\
\text { kelompok lain. }\end{array}$ \\
\hline
\end{tabular}

\section{Keunggulan dan Kekurangan Model Problem Basen Learning (PBL)}

Ada beberapa keunggulan dari penerapan model PBL pada siswa sekolah dasar. Dengan menerapkan model PBL siswa dapat dilatih kemampuan berpikir dalam menyelesaikan sebuah persoalan. Keunggulan lainnya antara lain, 1) mengembangkan 
kemmapuan berpikri kritis peserta didik, 2) menjadikan peserta didik sebagai aktor dalam proses pembelajaran, 3) peserta didik aktif untuk mencari informasi terkait materi yang dipelajarinya, 4) peserta didik belajar menganalisis suatu masalah, dan 5) mengembangkan rasa percaya diri peserta didik.

Namun dibalik keunggulan tentunya terdapat kelemahan. Kelemahan dari model PBL tersebut antara lain, 1) manakala peserta didik tidak memiliki minat atau tidak memiliki kepercayaan bahwa masalah dapat dipecahkan, maka peserta didik enggan untuk mencoba, 2) keberhasilan penerapan model PBL memerlukan waktu untuk persiapan.

\section{PBL untuk}

\section{menumbuhkembangkan HOTS}

Aspek kemampuan berpikir tingkat tinggi atau HOTS antara lain menganalisis, mengevaluasi, dan mengkreasi. Semua aspek tersebut menjadi bagian dari sintaks pembelajaran model PBL. Model PBL diterapkan sesuai dengan pandangan konstruktivis yang menekankan pada kebutuhan siswa untuk melakukan penyelidikan terhadap lingkungannya dan membangun pengetahuan yang bermakna secara pribadi. Sintaks pembelajaran dengan menggunakan model PBL yang dilaksanakan secara sitematis berpotensi dapat menumbuhkembangkan keterampilan berpikir tingkat tinggi (Higher Order Thinking Skill) siswa dalam menyelesaikan masalah dan sekaligus dapat memehami pengetahuan yang sesuai dengan kompetensi dasar tertentu. Hal itu lah yang menjadikan siswa memiliki kemampuan berpikir tingkat tinggi, karena mereka tidak hanya mendengarkan penjelasanpenjelasan dari guru melainkan menggali pengetahuan dan ketrampilannya sendiri.

\section{SIMPULAN}

Kemampuan berpikir tingkat tinggi atau lebih dikenal dengan HOTS perlu dilatihkan pada anak sekolah dasar. Kemampuan tersebut dapat muncul jika dilatihkan secara berkelanjutan pada siswa. Salah satu cara untuk melatihkan atau menumbuhkembangkan kamampuan tersebut adalah dengan cara menerapkan pembelajaran dengan menggunakan model Problem Based Learning (PBL).

Sintaks model PBL terdiri dari lima langkah utama yaitu 1) Orientasi siswa pada masalah, 2) Mengorganisasi siswa dalam pembelajaran, 3) Membimbing penyelidikan individual dan kelompok , 4) Mengembangkan dan menyajikan hasil karya, 5) Menganalisis dan mengevaluasi proses pemecahan masalah. Tahapantahapan pembelajaran dari model PBL tersebut menuntut siswa untuk berpikir high level. Dengan demikian penerapan model Problem Based Learning (PBL) dapat menumbuhkembangkan Higher Order Thinking Skill (HOTS) siswa Sekolah Dasar. 


\section{DAFTAR PUSTAKA}

Abbas, Tashakkori. 2010. Handbook of Mixed Methods In Social \& Behavioral Reseach. Jakarta: Pustaka Pelajar.

Arnyana, Ida Bagus Putu. 2007. Penerapan model PBL pada Pelajaran Biologi Untuk Meningkatkan Kompetensi dan Kemampuan Berpikir Kritis Siswa Kelas X SMA Negeri 1 Singaraja Tahun Pelajaran 2006/2007. Skripsi.

Danim, $\quad 2013$. Perkembangan Peserta Didik. Bandung: Alfabeta.

Hassoubah, Zaleha Izhab. 2007.Mengasah Pikiran Kreatif dan Kritis. Nuansa: Jakarta.

Hosnan. 2014. Pendekatan Saintifik dan Kontekstual dalam Pembelajaran Abad 21. Bogor: Ghalia Indonesia.

Setyorini, U. 2011. Penerapan Model Problem Based Learning Untuk Meningkatkan Kemampuan Berpikir Kritis Siswa SMP. Jurnal Pendidikan Fisika Indonesia 1 (2011) 52-56. ISSN: 1693-1246. Tersedia di http://sepfinanurulm.blogchem.co $\mathrm{m} / \mathrm{wp}-$ content/uploads/2016/12/berifik ir-kritis.pdf. Diunduh tanggal 24 Januari 2017.

Walker, Paul \& Finney, Nicholas. (2006). Skill Development and Critical Thinking in Higher Education. Higher Education Research \& Development Unit, University College, London WC1E 6BT, UK 